\title{
Integration of Iron Coagulant, Copperas and Calcium Hydroxide for Low-Cost Groundwater Treatment in Kelantan, Malaysia
}

\author{
Hakim C. Harun 1,2 (D), Fathini Fisol ${ }^{1}$ (D), Sofiah Hamzah ${ }^{1}$ (D), Fazureen Azaman ${ }^{1}$ (D), \\ Rohani Mustapha ${ }^{1,2}$ (D), Alyza A. Azmi ${ }^{2}$ (D), Nurul Aqilah Mohamed ${ }^{1}$ (D), Izzah Zakirah ${ }^{1}$ (D), \\ Ariff Fahmi Mustofa 4 (D), Asmadi Ali 1,2,* (D) \\ 1 Faculty of Ocean Engineering Technology and Informatics, Universiti Malaysia Terengganu, 21030 Kuala Nerus, \\ Terengganu, Malaysia \\ 2 Environmental Sustainable Material Research Interest Group, Faculty of Ocean Engineering, Technology, and Informatics, \\ Universiti Malaysia Terengganu, 21030 Kuala Nerus, Terengganu Malaysia \\ 3 Faculty of Science and Marine Environment, Universiti Malaysia Terengganu, 21030 Kuala Nerus, Terengganu, Malaysia \\ 4 Venator Asia Sdn Bhd, Teluk Kalung Industrial Area, 24007, Terengganu, Malaysia \\ * Correspondence: asmadi@umt.edu.my (A.A.);
}

Scopus Author ID 54790692100

Received: 28.02.2021; Revised: 20.04.2021; Accepted: 25.04.2021; Published: 9.05.2021

Abstract: In Kelantan, more than $70 \%$ of domestic water is supplied by groundwater sources. These water sources are commonly contaminated and do not meet the World Health Organization (WHO) drinking water standard and the Malaysian Ministry of Health (MMOH). This research's main objective is to study the performance of iron-based coagulants Ferrous Sulphate on its optimum dosage, formulation, and concentration. Series of jar tests are conducted by adding and comparing five different copperas solution concentrations from $15 \%$ to $0.6 \%$ into the $500 \mathrm{~mL}$ beaker. The prepared copperas solutions are combined with lime (calcium hydroxide), and the performance of with (copperas plus) and without lime are compared. The results obtained show that copperas plus has a far better performance compared to copperas solution. The copperas plus results comply with the drinking water standard for $\mathrm{pH}$ value (6.5-8.5) and turbidity (below $5 \mathrm{NTU}$ ). Copperas and turbidity removal efficiency are between $89 \%$ and $99 \%$, while copperas has a lower range of turbidity removal efficiency, $72.9 \%$ and $97.7 \%$. Most of the results obtained do not comply with the drinking water standard of iron $(\mathrm{Fe})$ and Manganese (Mn) over 0.3 and $0.1 \mathrm{mg} / \mathrm{L}$, respectively. However, the potential of copperas and copperas plus to treat domestic drinking water could be improvised by further studying its dosing effect on heavy metal content.

Keywords: coagulation; drinking water; flocculation; iron coagulants; water treatment.

(C) 2021 by the authors. This article is an open-access article distributed under the terms and conditions of the Creative Commons Attribution (CC BY) license (https://creativecommons.org/licenses/by/4.0/).

\section{Introduction}

Water treatment system such as filtration and coagulation has recently been developed to achieve a reliable world domestic water security [1]. Coagulation and flocculation is one of the most conventional water treatments and applied by most countries in the world, such as Malaysia, Malawi, United Kingdom, and China [2-4]. In Malaysia, main water treatment consortiums such as Air Selangor (SYABAS), Air Kelantan Sdn. Bhd. (AKSB) and Air Terengganu (SATU) have been using Aluminum Sulphate $\left(\mathrm{Al}_{2} \mathrm{SO}_{4}\right)$ and Polyaluminum Chloride (PAC) to treat the incoming water from the local river. 
These water treatment consortiums utilize and collect water from the local river. Due to some geopolitical and water characteristic issues, the treatment facilities and piping system in some parts of Malaysia are not developed evenly [5]. Complaints about unsatisfactory water services in Kelantan have led Environment Sustainable Materials Research Group to collaborate with Yayasan Amal Malaysia to research feasible and cheaper ways to treat their water. In Kelantan, where the water facilities are not provided or insufficient, communities build a tube well for domestic water supply. The tube's depth and location are scattered all over the region without the water supply facilities. This resulted in various quality and quantity of water distributed domestically.

This research investigates iron coagulant, Ferrous Sulphate performance on the treated water quality of tube-well in Kelantan. Ferrous Sulphate, commonly known as copperas, is a natural by-product of the titanium oxide $\left(\mathrm{TiO}_{2}\right)$ supplied by Venator Asia Sdn Bhd [6]. The performances of the copperas are investigated to find their optimum concentration, dosing amount, and formulation. Standard drinking water parameters such as turbidity, $\mathrm{pH}$ value, and metal contents are tested if the copperas performance met the drinking water standard shown in Table 1. The values, however, are subjective to the condition of the application and treatment system. For example, Manganese, Mn should not exceed $0.2 \mathrm{mg} / \mathrm{L}$ instead of $0.1 \mathrm{mg} / \mathrm{L}$ for a small water treatment plant that serves under 10,000 people [7].

Table 1. National Water Quality Standard for Malaysia [7,8].
\begin{tabular}{c|c|c} 
PARAMETER & SPECIFICATION & UNIT \\
\hline $\mathrm{pH}$ & $6.5-8.5$ & - \\
\hline Turbidity & 5 & $\mathrm{NTU}$ \\
\hline Color & 15 & $\mathrm{TCU}$ \\
\hline Total Dissolved Solid & 500 & $\mathrm{mg} / \mathrm{L}$ \\
\hline Total Coliform & 100 & $\mathrm{count} / 100 \mathrm{~mL}$ \\
\hline Aluminum, Al & 0.1 & $\mathrm{mg} / \mathrm{L}$ \\
\hline Iron, Fe & 0.3 & $\mathrm{mg} / \mathrm{L}$ \\
\hline Manganese, Mn & 0.1 & $\mathrm{mg} / \mathrm{L}$ \\
\hline Lead, Pb & 0.01 & $\mathrm{mg} / \mathrm{L}$
\end{tabular}

Aluminum-based coagulants such as Aluminium Sulphate (Alum) and Polyaluminum Chloride (PAC) hydrolyze the metal ion, Aluminum, to form aluminum hydroxide floc [9]. Similarly, for copperas, iron ion reaction with water would produce ferrous hydroxide and hydrogen ion as shown in Equation (1). The hydrogen ion produced would react with the water's alkalinity, subsequently reducing the $\mathrm{pH}$ value [10]. Since copperas itself poses an acidic property, hence, copperas is very suitable to be used with high alkalinity effluent.

$$
\mathrm{FeSO}_{4} \cdot 7 \mathrm{H}_{2} \mathrm{O} \rightarrow \mathrm{Fe}^{2+}+\mathrm{SO}_{4}^{2-}+7 \mathrm{H}_{2} \mathrm{O} \rightarrow \mathrm{Fe}(\mathrm{OH})_{2}+\mathrm{SO}_{4}^{2-}+2 \mathrm{H}^{+}+5 \mathrm{H}_{2} \mathrm{O}
$$

Sillanpää and Matilainen [11] mention that copperas is good in natural organic content (NOM) removal and better temperature change performance than Alum. At low coagulant doses, copperas' floc formation was found to be more compact and larger in size [12]. Copperas at high dosage, however, would affect the collision rate of destabilized colloids and known to be higher in alkalinity consumption. This would cause greater chemical addition for stabilization and corrosion control. 


\section{Materials and Methods}

\subsection{Raw water sampling.}

The water source is collected, and on-site testing is done for the initial value of raw water. Common parameters such as $\mathrm{pH}$ value, turbidity, and metal content are tested within the time frame and preservation techniques suggested by ALS Technichem Sdn. Bhd.

\subsection{Coagulant-copperas powder.}

Copperas powder collected from the Venator Asia Sdn Bhd. Copperas is the iron salts produced by Venator Asia Sdn $\mathrm{Bhd}$ as $\mathrm{TiO}_{2}$ co-products that are sold worldwide for various applications. These include animal feedstocks, construction materials, and fertilizers [13]. The yellowish color of the copperas indicates the materials have been exposed to the air for a longer period. The oxidized and degraded materials are avoided in this experiment. To avoid materials oxidation, copperas is stored in air-tight containers and keep the greenish color shown in Figure 2.

\subsection{Coagulant preparation.}

This research aims to find the optimum formulation of copperas for underground water. A few concentrations of copperas and copperas plus solution $\mathrm{X} \%$ are prepared.

Table 2 shows the composition of the copperas and copperas plus the mixture in $1 \mathrm{~L}$ of water used in this experiment. The copperas powder obtained from Venator Asia Sdn Bhd is weighted according to the required concentration and well mixed in distilled water using a magnetic stirrer for at least 30 minutes.

Table 2. Copperas and Copperas Plus Solution X \% w/v.

\begin{tabular}{c|c|c|c} 
Concentration, $\mathbf{X}(\%)$ & Copperas (g) & \multicolumn{2}{|c}{ Copperas Plus (80\% Copperas + 20 \% Lime) } \\
\cline { 3 - 4 } & & Copperas (g) & Lime (g) \\
\hline 15 & 150 & 120 & 30 \\
\hline 6 & 60 & 48 & 12 \\
\hline 5 & 50 & 40 & 10 \\
\hline 3 & 30 & 24 & 6
\end{tabular}

\subsection{Experimental set-up and dosing calculation.}

For jar test experiment, 500mL of raw water sample from Kg. Panjang Kota Bharu, Kelantan are prepared in five beakers. The dosing value is calculated by using Eq. 2. Standard operating procedures of the jar test are applied. Rapid mixing is set to be $150 \mathrm{rpm}$ for 2 minutes and continues for slow mixing using $30 \mathrm{rpm}$ for another 30 minutes.

Equation (2) determined the dosing and amount of copperas solution $(\mathrm{mL})$ needed. For example, $1.67 \mathrm{~mL}$ of copperas $15 \% \mathrm{w} / \mathrm{v}$ solutions are needed for $100 \mathrm{mg} / \mathrm{L}$ of chemical dosing in $500 \mathrm{~mL}$ of samples.

$$
C_{1} \cdot V_{1}=C_{2} \cdot V_{2}
$$

Where,

$\mathrm{V}_{1}=$ volume of starting solution needed to make the new solution

$\mathrm{C}_{1}=$ concentration of starting solution

$\mathrm{V}_{2}=$ final volume of new solution

$\mathrm{C}_{2}=$ final concentration of new solution 


\subsection{Analytical test.}

The turbidity of raw and treated samples was tested using Thermo Scientific Aquafast AQ3010. pH meter use is Orion X50. The machine has been calibrated and serviced accordingly. Metal content such as Iron $(\mathrm{Fe})$ and Manganese $(\mathrm{Mn})$ of the raw and treated sample is tested using Varian SpectrAA FS-220 Atomic Absorption Spectroscopy.

\section{Results and Discussion}

Overall, the experimental works was a success. Figure 1 shows the untreated and treated sample of underground water collected from Kelantan. Turbidity removal was high, up to 99 $\%$. The coagulation and flocculation process forming a good floc for sedimentation was affirmative. The clear water after the sedimentation process shown in Figure 1(b) complied with the drinking water standard by World Health Organization (WHO), below 5NTU.

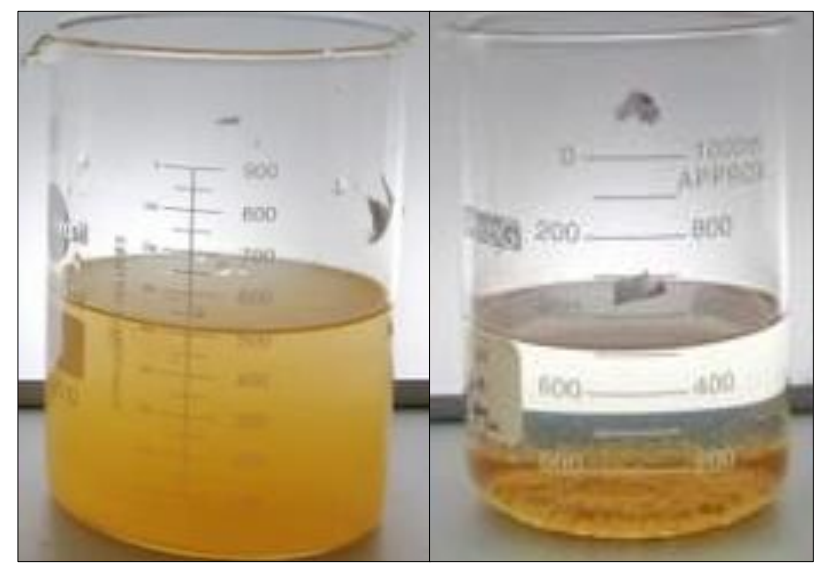

(a)

(b)

Figure 1. shows the (a) untreated and (b) treated underground water by using Copperas.

Table 3 shows the properties of raw water prior to the copperas treatment. Most of the initial value exceeded the World Health Organization (WHO) limit and Malaysia Authorities drinking water standard. In this research, since the optimum copperas formulation (X \%) is first to be tested, turbidity removal would be among the first parameters to be observed. Iron content is the second important parameter to be observed as copperas is an iron-base coagulant.

Table 3. Raw Water Properties of Underground Water.

\begin{tabular}{l|l|l} 
PARAMETER & VALUE & UNIT \\
\hline $\mathrm{pH}$ & 6.960 & - \\
\hline Turbidity & 160.33 & $\mathrm{NTU}$ \\
\hline Total Dissolved Solids (TDS) & 150.55 & $\mathrm{Mg} / \mathrm{L}$ \\
\hline Magnesium, Mg & 1.972 & $\mathrm{mg} / \mathrm{L}$ \\
\hline Iron, Fe & 0.822 & $\mathrm{mg} / \mathrm{L}$ \\
\hline Manganese, Mn & 0.175 & $\mathrm{mg} / \mathrm{L}$ \\
\hline Lead, $\mathrm{Pb}$ & 0.0853 & $\mathrm{mg} / \mathrm{L}$
\end{tabular}

A simple jar test was carried out to simulate the flocculation and coagulation of copperas and copperas plus. Figure 2 shows the effect of copperas dosing on the final turbidity of treated water. Both chemicals (copperas plus and copperas) show a positive coagulation profile where the final turbidity value reduced significantly overdosing value. The raw water's initial turbidity shows in Table 3 shows initial turbidity of raw water is 160.33 NTU. Figure 2(a) represents the effect of copperas dosing on final turbidity using various concentrations, $\mathrm{X}$ 
$\%$ of Copperas. In this case, copperas formulation of $15 \%$ concentration shows the best turbidity performance, followed by $6 \%, 3 \%$, and $0.6 \%$. These results agree with Mbaeze $e t$ al. [9], and Guan et al. [3] stated that the higher the coagulant dosage, the higher the turbidity removal. Drinking water standard requires the turbidity of 5 NTU or lower, and copperas dosing for all formulation and dosing does not meet the standard.

Copperas Plus, however, shows a lower final turbidity value which favorable to water treatment industries. The lower range of final turbidity shown in Figure 2(b), ranging from 12.9 to $1.37 \mathrm{NTU}$, was recorded. In this case, copperas plus's performance is proven to be more efficient where most of the data obtained to meet the drinking water standard of turbidity below $5 \mathrm{NTU}$ except for $1 \%$. This is due to the properties and alkalinity of lime that would work as a bridging agent for copperas in the coagulation and flocculation process [14]. Christensen and Stule [14] stated that iron salts had been better conditioning with lime than without lime.

Final Turbidity vs. Copperas Dosing

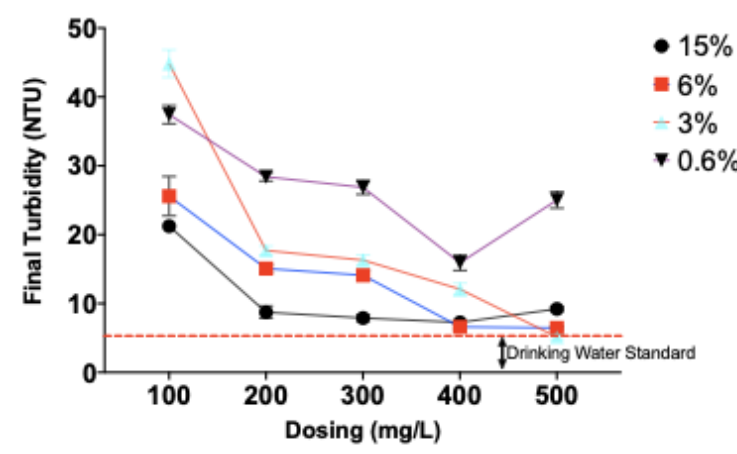

(a)
Final Turbidity vs. Copperas Plus Dosing

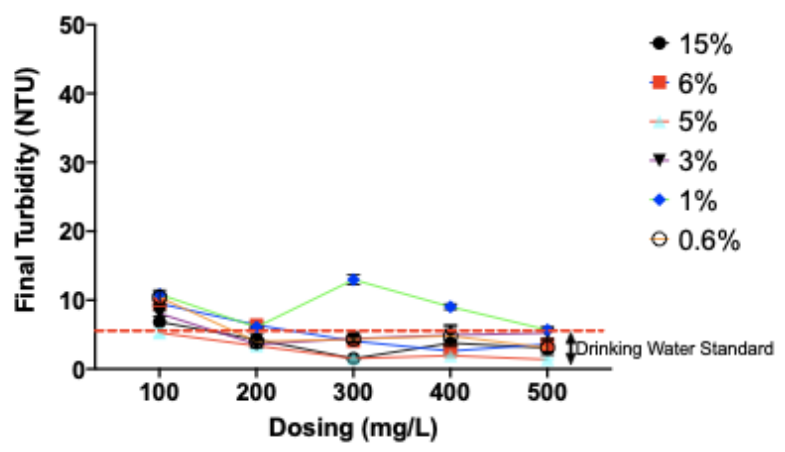

(b)

Figure 2. Final turbidity of treated underground water by using (a) Copperas; (b) Copperas Plus.

Figure 3 shows a set of turbidity removal data for (a) copperas and (b) copperas plus dosing. It is proven that the efficiency of the copperas plus is higher compare to copperas dosing. A similar trend is found where the higher the dosing amount, the higher the turbidity removal efficiency. Copperas plus shows the lowest turbidity removal of $89 \%$ and the highest removal of $99 \%$. The turbidity removal is at the highest performance by using $400 \mathrm{mg} / \mathrm{L}$ of copperas plus dosing, achieving the final 99\% removal and final turbidity value of 1.04 NTU. Contradictory, copperas dosing efficiency range is lower, $72.9 \%$ to $97.7 \%$.

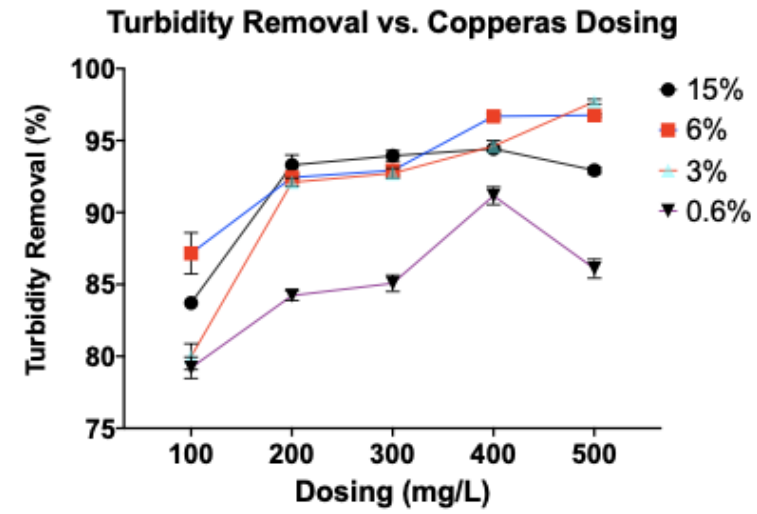

(a)

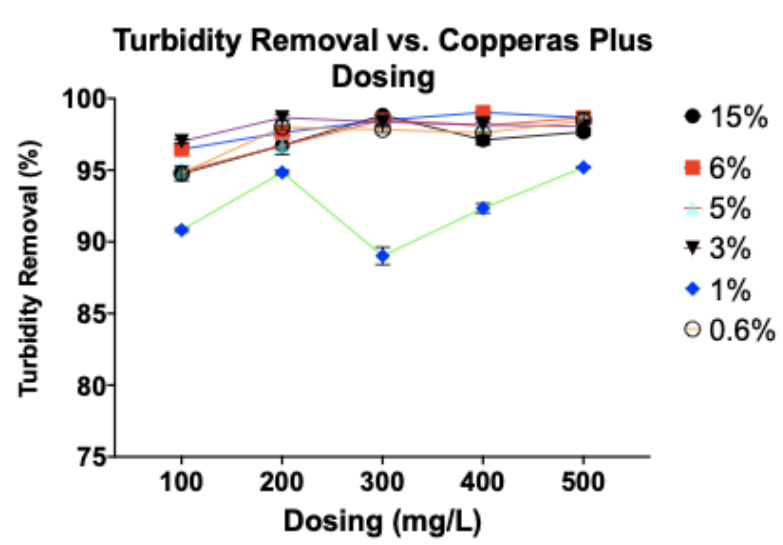

(b)

Figure 3. Turbidity removal (\%) of treated underground water by using (a) Copperas; (b) Copperas Plus. 
Another important drinking water parameter is the $\mathrm{pH}$ value. The alkalinity and acidity of water needed to be within 6.5 to 8.5 for drinking. Figure 4 shows the treated water sample's final $\mathrm{pH}$ value using copperas and copperas plus different concentrations and doses. Figure 4(a) clearly shows that most treated water collected is out of the $\mathrm{pH}$ value range for drinking water. The treatments resulted in increasing the acidity of raw water from 6.96 to 5.56. Theoretically, iron salts coagulant hydrolyzes into hydrogen ion to reduce the water's alkalinity $[9,11] . \mathrm{pH}$ value for $0.6 \%$ by using 100 and $200 \mathrm{mg} / \mathrm{L}$ of dosing met the drinking water standard. The condition inferred that the lower the iron salts injected, the lower the hydrogen ion generated to reduce the alkalinity of water.

Figure $4(\mathrm{~b})$ is the $\mathrm{pH}$ value of the treated underground water by using copperas plus. The entire data shows a positive outcome where all tested concentrations and doses met the $\mathrm{pH}$ value range for drinking water standard. The concentration of $6 \%$ shows the best $\mathrm{pH}$ value range of between 7.0 and 7.5. This finding shows that a chemical formulation of copperas lime combination is better than without lime. Copperas plus formulation has shown a possible and better way for $\mathrm{pH}$ stabilization than pre and posts lime operation. This improvement includes reducing the cost of operation, equipment, and materials consumption.

Final pH vs. Copperas Dosing

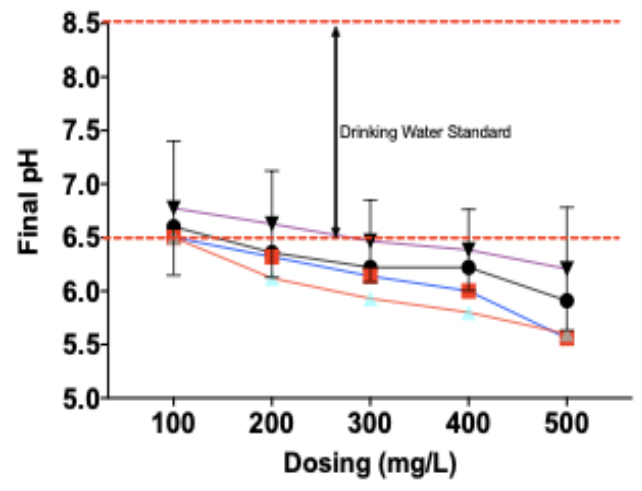

(a)
Final pH vs. Copperas Plus Dosing

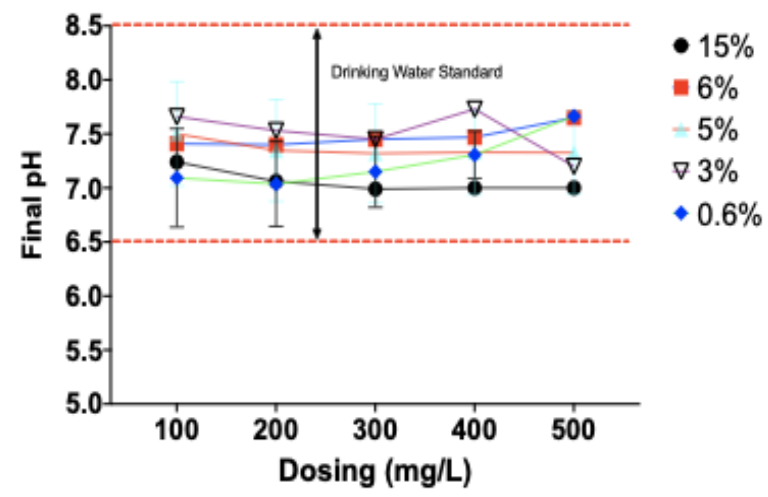

(b)

Figure 4. Final $\mathrm{pH}$ value of treated underground water by using (a) Copperas; (b) Copperas Plus.

Since copperas plus has shown a better $\mathrm{pH}$ and turbidity performance, heavy metal content has been tested. In Malaysia, concisely in the Kelantan region, iron and manganese content in their drinking water has been a concern [15].

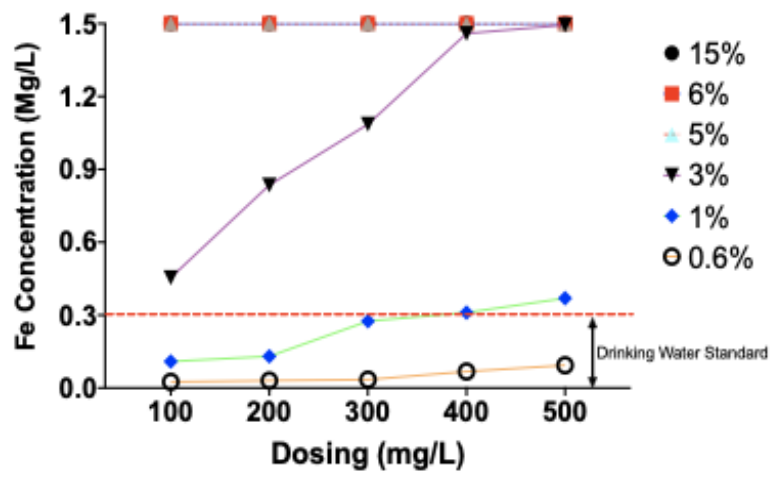

(a)

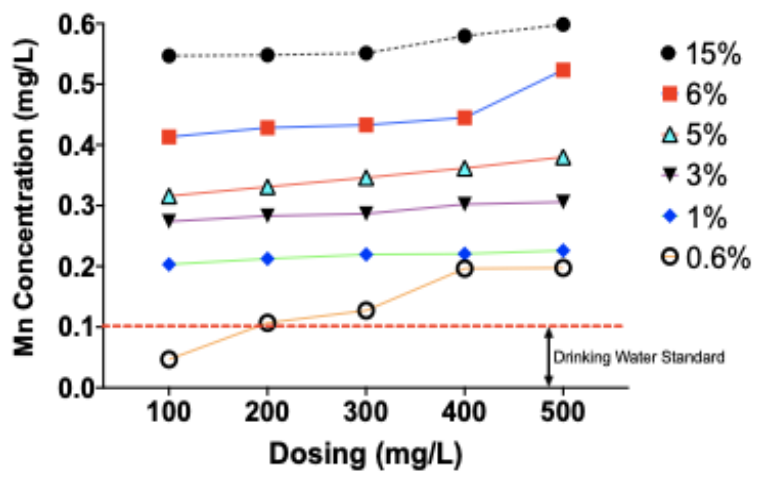

(b)

Figure 5. Metal content of treated underground water by using Copperas Plus (a) Iron, Fe; (b) Manganese, Mn. 
Figure 5 shows most of the iron content and manganese content is over the permissible range of drinking water standards. The treated water in Figures 5(a) and (b) shows iron and manganese concentration exceeds its initial value. This means that copperas, iron-based coagulants, indirectly contaminates the water with the heavy metal iron. For underground water, this treatment concentration and dosing show a sign of coagulant overdosing.

\section{Conclusions}

Copperas plus solution has shown better performance in treating groundwater in Kelantan compared to copperas. The buffer properties of lime combined with copperas improvised the coagulation efficiency. Lime plays an important role as 'bridging agent' for a better floc formation. Turbidity removal in this study using copperas plus is higher, and most of the final turbidity values were recorded to comply with the drinking water quality standard by $\mathrm{WHO}$ and $\mathrm{MMOH}$. A similar trend of results using aluminum coagulants is obtained, where the higher the dosing amount, the higher turbidity removal efficiency. Copperas plus comply with drinking water quality standard of $\mathrm{pH}$ value between 6.5 and 8.5 and turbidity below 5 NTU. The best copperas plus solution formulation is $6 \%$. While for copperas, the results stated otherwise, drinking water quality standards have not complied. The results, however, represent the unsuitability of using both copperas and copperas plus for heavy metal iron (Fe) and Manganese $(\mathrm{Mn})$ removal. The concentration of heavy metal content exceeds the limit of $\mathrm{Fe}$ and $\mathrm{Mn} 0.3$ and $0.1 \mathrm{mg} / \mathrm{L}$, respectively. This research would recommend further studies on the effect of dosing in heavy metal removals using copperas plus solutions. Copperas dosing is very sensitive towards Fe residue. Thus a 'sweet spot' of overdosing and underdosing would break through copperas' potential to treat groundwater.

\section{Funding}

This research received no external funding.

\section{Acknowledgments}

The authors are thankful to the Universiti Malaysia Terengganu for providing facilities for this research.

\section{Conflicts of Interest}

The authors declare no conflict of interest.

\section{References}

1. Opperman, J. J.; Orr, S.; Baleta, H.; Garrick, D.; Goichot, M.; McCoy, A.; Morgan, A.; Schmitt, R.; Turley, L.; Vermeulen, A. Achieving water security's full goals through better integration of rivers' diverse and distinct values. Water Security 2020, 10, 1-7, https://dx.doi.org/10.1016/j.wasec.2020.100063.

2. Bitton, G. Water treatment technologies for developing countries. Microbiology of Drinking Water 2014, 173-194, https://dx.doi.org/10.1002/9781118743942.ch8.

3. Guan, D.; Zhang, Z.; Li, X.; Liu, H. Effect of $\mathrm{pH}$ and temperature on coagulation efficiency in a North-China water treatment plant. Advanced Materials Research 2011, 243-249, 4835-4838, https://dx.doi.org/10.4028/www.scientific.net/AMR.243-249.4835.

4. Pritchard, M.; Mkandawire, T.; Edmondson, A.; O'Neill, J. G.; Kululanga, G. Potential of using plant extracts for purification of shallow well water in Malawi. Physics and Chemistry of the Earth 2009, 34, 799-805, https://dx.doi.org/10.1016/j.pce.2009.07.001. 
5. Besar, J.A.; Fauzi, R.; Ghazali, A. S.; Jali, M. F. M.; Lyndon, N.; Ali, M. Impak pembangunan perumahan terhadap geopolitik bandar (an impact of housing development to urban geopolitic). Akademika 2012, 82, 49-60.

6. Han, J.; Zhang, J.; Feng, W.; Chen, X.; Zhang, L.; Tu, G. A clean process to prepare high-quality acidsoluble titanium slag from titanium middling ore. Minerals 2019, 9, 1-14, https://dx.doi.org/10.3390/min9080460.

7. World Health Organization. Guidelines for Drinking-Water Quality (World Health Organization, Ed.). WHO. 2012.

8. Ministry of Natural Resources and Environment Malaysia. National Water Quality Standards For MalaysiaAnnex. National Water Quality Standards for Malaysia- Annex. 2014.

9. Mbaeze, M.; Agbazue, V.; Orjioke, N. Comparative assessment of performance of aluminium sulphate (alum) and ferrous sulphate as coagulants in water treatment. Modern Chemistry \& Applications 2017, 5, 114, https://dx.doi.org/10.4172/2329-6798.1000233.

10. Andrés-Bello, A.; Barreto-Palacios, V.; García-Segovia, P.; Mir-Bel, J.; Martinez-Monzo. J. Effect of pH on color and texture of food products. Food Engineering Reviews 2013, 5, 158-170, https://doi.org/10.1007/s12393-013-9067-2.

11. Sillanpää, M.; Matilainen, A. NOM Removal by Coagulation. In Natural organic matter in water: characterization and treatment menthods. Elsevier Inc. 2015.

12. Siéliéchi, J. M.; Lartiges, B. S.; Kayem, G. J.; Hupont, S.; Frochot, C.; Thieme, J.; Ghanbaja, J.; d'Espinose de la Caillerie, J. B.; Barrès, O.; Kamga, R.; Levitz, P.; Michot, L. J. Changes in humic acid conformation during coagulation with ferric chloride: implications for drinking water treatment. Water Research 2008, 42, 2111-2123, https://doi.org/10.1016/j.watres.2007.11.017.

13. Gates, K. W., \& Simon, N. R. Process for the production of ferrous sulphate monohydrate. United States: US Patents Application 2013, 2-6, https://patents.google.com/patent/US20130052106A1/en

14. Deneux-Mustin, S.; Lartiges, B.; Villemin, G.; Thomas, F.; Yvon, J.; Bersillon, J.; Snidaro, D. Ferric chloride and lime conditioning of activated sludges: An electron microscopic study on resin-embedded samples. Water Research 2001, 35, 3018-3024, https://doi.org/10.1016/S0043-1354(01)00003-3.

15. Ab Razak, N. H.; Praveena, S. M.; Aris, A. Z.; Hashim, Z. Drinking water studies: a review on heavy metal, application of biomarker and health risk assessment (a special focus in Malaysia). Journal of Epidemiology and Global Health 2015, 5, 297-310, https://dx.doi.org/10.1016/j.jegh.2015.04.003. 